\title{
ARTICLE
}

\section{Lithogeochemistry of the meta-igneous units from Arroio Grande Ophiolitic Complex, southernmost Brazil}

\author{
Litogeoquímica das unidades meta-ígneas do
} Complexo Ofiolítico Arroio Grande, extremo sul do Brasil

\author{
Rodrigo Chaves Ramos ${ }^{1 *}$, Edinei Koester ${ }^{2}$
}

\begin{abstract}
Ophiolites are defined as slices of genetically-related upper mantle serpentinized peridotites and oceanic crustal rocks, tectonically displaced from its primary igneous origin of formation by plate convergence and associated (meta) sedimentary rocks of marine origin. From this premise, a meta-ultramafic-mafic-sedimentary complex (Cr-rich magnesian schists - upper mantle or crustal ultramafic cumulate candidates; epidote amphibolites, metadiorites and metagabbros - oceanic crust candidates; metasedimentary schists, quartzites and marbles - marine sedimentary rocks candidates), located in southeastern Dom Feliciano Belt (southernmost Brazil), started to be interpreted as possible slices of an ophiolitic complex related to the closure of a paleo-ocean during Brasiliano/Pan-African orogenic cycle and was called Arroio Grande Ophiolitic Complex. The present research fills the lack of geochemical data from previous studies and tests the hypothesis of an oceanic setting for the meta-igneous units of this complex from a lithogeochemistry point of view. The meta-ultramafics were interpreted as peridotites (mantle or crustal cumulates) that were subsequently serpentinized (probably in the ocean floor) and posteriorly metasomatized (probably in a continental setting). The meta-mafics were interpreted as oceanic gabbros/basalts formed in a back-arc basin. The results, together with field relationships, rock associations and petrographic evidences, support an oceanic origin for the protoliths of the meta-igneous units. The hypothesis that these rocks represent metamorphosed slices of an ophiolitic complex is still the most reasonable one. This work updates the geologic knowledge of the area and supports discussions about the evolution of Dom Feliciano Belt and Western Gondwana paleocontinent.
\end{abstract}

KEYWORDS: Metasomatism; Meta-serpentinites; Amphibolites; Supra-subduction zone; Back-arc.
RESUMO: Ofiolitos são definidos como fragmentos de peridotitos mantélicos serpentinizados e rochas crustais oceânicas, geneticamente relacionados e tectonicamente deslocados de sua origem ignea primária por convergência tectônica e de rochas (meta) sedimentares marinhas associadas. Partindo dessa premissa, um complexo meta-ultramáfico-máfico-sedimentar (xistos magnesianos cromiferos - candidatos à origem mantélica ou cumulática ultramáfica crustal; epidoto anfibolitos, metadioritos e metagabros - candidatos à origem oceânica; xistos metassedimentares, quartzitos e mármores - candidatos a rochas sedimentares marinhas), localizado no sudeste do Cinturáo Dom Feliciano (extremo sul do Brasil), passou a ser interpretado como possiveis fragmentos de um complexo ofiolítico relacionado ao encerramento de um paleo-oceano durante o ciclo orogênico Brasiliano/Pan-Africano, definido como Complexo Ofiolitico Arroio Grande. A presente pesquisa preenche a ausência de dados geoquímicos de trabalhos anteriores e testa, do ponto de vista litogeoquímico, a hipótese de uma origem oceânica para as unidades meta-igneas desse complexo. Os metaultramafitos foram interpretados como peridotitos (mantélicos ou cumulatos ultramáficos crustais) que foram serpentinizados (provavelmente no assoalho oceânico) e posteriormente metassomatizados (provavelmente em um contexto continental). Os metamafitos foram interpretados como gabros/basaltos oceânicos gerados em uma bacia de trás-arco. Os resultados deste estudo, juntamente com as relaçooes de campo, associaçóes litológicas e evidências petrográficas, suportam uma origem oceânica para os protólitos das unidades meta-igneas e a hipótese de que tais rochas representam fragmentos metamorfizados de um complexo ofiolitico é ainda a mais adequada. Este trabalho atualiza o conhecimento geológico da regiäo, contribuindo para as discussóes acerca da evolução do Cinturão Dom Feliciano e do paleocontinente Gondwana Ocidental.

PALAVRAS-CHAVE: Metassomatismo; Meta-serpentinitos; Anfibolitos; Zona de supra-subducção; Trás-arco.

\footnotetext{
${ }^{1}$ Programa de Pós-Graduação em Geociências, Instituto de Geociências, Universidade Federal do Rio Grande do Sul - UFRGS, Porto Alegre (RS), Brazil. E-mail: rodrigo.chaves@ufrgs.br

${ }^{2}$ Departamento de Geologia, Instituto de Geociências, Universidade Federal do Rio Grande do Sul - UFRGS, Porto Alegre (RS), Brazil. E-mail: koester@ufrgs.br *Corresponding author.

Manuscrito ID: 30127. Recebido em: 11/06/2014. Aprovado em: 23/01/2015.
} 


\section{INTRODUCTION}

Ophiolites are defined as slices of upper mantle and oceanic crust, tectonically displaced from their primary igneous origin of formation by plate convergence. They are frequently represented by a genetically-related rock association of partly to totally serpentinized upper mantle peridotites and crustal ultramafic cumulates, (meta) gabbros/basalts, volcanic units with or without sheeted dikes and (meta) sedimentary rocks of marine origin. Modern studies, like Dilek and Newcomb (2003), Dilek and Robinson (2003), Kusky et al. (2011), Dilek and Furnes $(2011,2014)$, have shown that the full Penrose layer-cake sequence defined in Anonymous (1972) represents only $\approx 10 \%$ of the Phanerozoic ophiolitic complexes and that the variations between individual ophiolites are as significant as their similarities, making it difficult to define a type succession. Furthermore, Precambrian ophiolites are frequently metamorphosed and dismembered, with some missing units (Kusky et al. 2011).

From these premises, a meta-ultramafic-mafic-sedimentary rock association (Cr-rich magnesian schists - candidates for upper mantle or ultramafic cumulate origin; epidote amphibolites, metadiorites and metagabbros — candidates for oceanic crust origin; metasedimentary schists, quartzites and marbles candidates for sedimentary rocks of marine origin), located in southeastern Dom Feliciano Belt (southernmost Brazil), began to be interpreted as possible metamorphosed slices of an ophiolitic complex related to the closure of a paleo-ocean during the Brasiliano/Pan-African Orogenic Cycle (Ramos \& Koester 2013; Ramos et al. 2013; Ramos \& Koester 2014). The previous works were based mainly on field relationships and petrographic similarities with other complexes (e.g. Abadiânia, Goias State, Brazil — Strieder \& Nelson 1992; Cerro Mantiqueiras, Rio Grande do Sul State, Brazil — Leite 1997; Antiforme Capané, Rio Grande do Sul State, Brazil — Marques et al. 2003; Cerro La Tuna, Cerro Largo Department, Uruguay — Peel et al. 2009; Marmora Terrane, Karas Region, Namibia — Frimmel 2011).

The present study aimed to fill the lack of geochemical data and to test the hypothesis of an oceanic crust and mantle origin for the Arroio Grande Ophiolitic Complex meta-ultramafic-mafic units from a lithogeochemical point of view, updating the geologic knowledge of the area and contributing to discussions about Dom Feliciano Belt and Western Gondwana paleocontinent evolution during Neoproterozoic.

\section{Regional geology}

The Arroio Grande Ophiolitic Complex is located at the southern portion of Dom Feliciano Belt (Rio Grande do Sul State, Brazil), a Neoproterozoic orogenic belt developed during the Brasiliano/Pan-African Orogenic Cycle. The belt extends for about 1,200 km from Punta del Este (Uruguay) to Santa Catarina State (Brazil). In Rio Grande do Sul State, it represents almost entirely the Sul-rio-grandense Shield and is divided into three geophysical domains: Eastern, Central and Western Domains (Fig. 1; Lenz et al. 2013).

In the southern portion of the Eastern Domain, where the Arroio Grande Ophiolitic Complex is located, granitoids from Pinheiro Machado Complex dominate over other lithologies (Fig. 2). These granitoids are gray, have equigranular to porphyric textures, predominantly granodioritic composition, calc-alkaline affinity, U-Pb ages between $610 \pm 5$ and $612 \pm 2 \mathrm{Ma}$ and are interpreted as subduction-related active continental margin granitoids (Fernandes et al. 1995; Babinski et al. 1997; Philipp et al. 2002; Ramos \& Koester 2014). Within the Pinheiro Machado Complex, the Piratini Gneisses (metric to decametric xenoliths with tonalitic to granodioritic composition, $\mathrm{U}-\mathrm{Pb}$ ages of $781 \mathrm{Ma}$ ) and the Basement Septa unit (mega-xenoliths of calc-silicate gneiss, biotite-rich gneiss, amphibolite, quartzite, and schist, U-Pb ages of $781 \pm 5 \mathrm{Ma}$ ) are found and interpreted as Early Brasiliano crust remnants and Paleo to Mesoproterozoic basement septa (Fragoso César et al. 1986; Figueiredo et al. 1990; da Silva et al. 1999; Wildner et al. 2005).

\section{Local geology}

The Arroio Grande Ophiolitic Complex is a meta-ultramafic-mafic-sedimentary rock association, cut in two by a large granitic body (Três Figueiras granite) and affected by ductile shear zones (Ayrosa Galvão and Arroio Grande shear zones) with $\mathrm{N} 50-80^{\circ} \mathrm{E}$ and secondary $\mathrm{E}-\mathrm{W}$ directions. In the northern area, centimetric to kilometric xenoliths of the three main units (meta-ultramafic, meta-mafic and metasedimentary) occur within Pinheiro Machado Complex granitoids (Fig. 2A). In the southern area, the biggest meta-ultramafic and meta-mafic bodies are found (Fig. 2B).

The meta-ultramafic unit is represented by talc-serpentine schists, tremolitites and chloritites. Based on petrographic comparison with similar occurrences found in the literature (e.g. Strieder 1992; Hartmann \& Remus 2000) and microscopic features, they were interpreted in previous works (Ramos 2011; Ramos \& Koester 2014) as the product of contact metasomatism between serpentinites and chemically contrasting rocks, forming fronts of talcification, tremolitization and chloritization from a serpentinite core.

These rocks form NE-SW metric to decametric discontinuous elongated bodies (Fig. 3A) are fine to medium grained, show sub-vertical millimetric schistosity, sub-horizontal stretching lineation and frequently show folds. The less competent talc-rich schists locally show crenulation cleavages. The meta-ultramafics are commonly found together in the same outcrop in diffuse to gradational contacts (Fig. 3B). No relict igneous minerals (except probably the chromites) or textures are preserved. Intensive alteration makes it difficult to study this unit. 


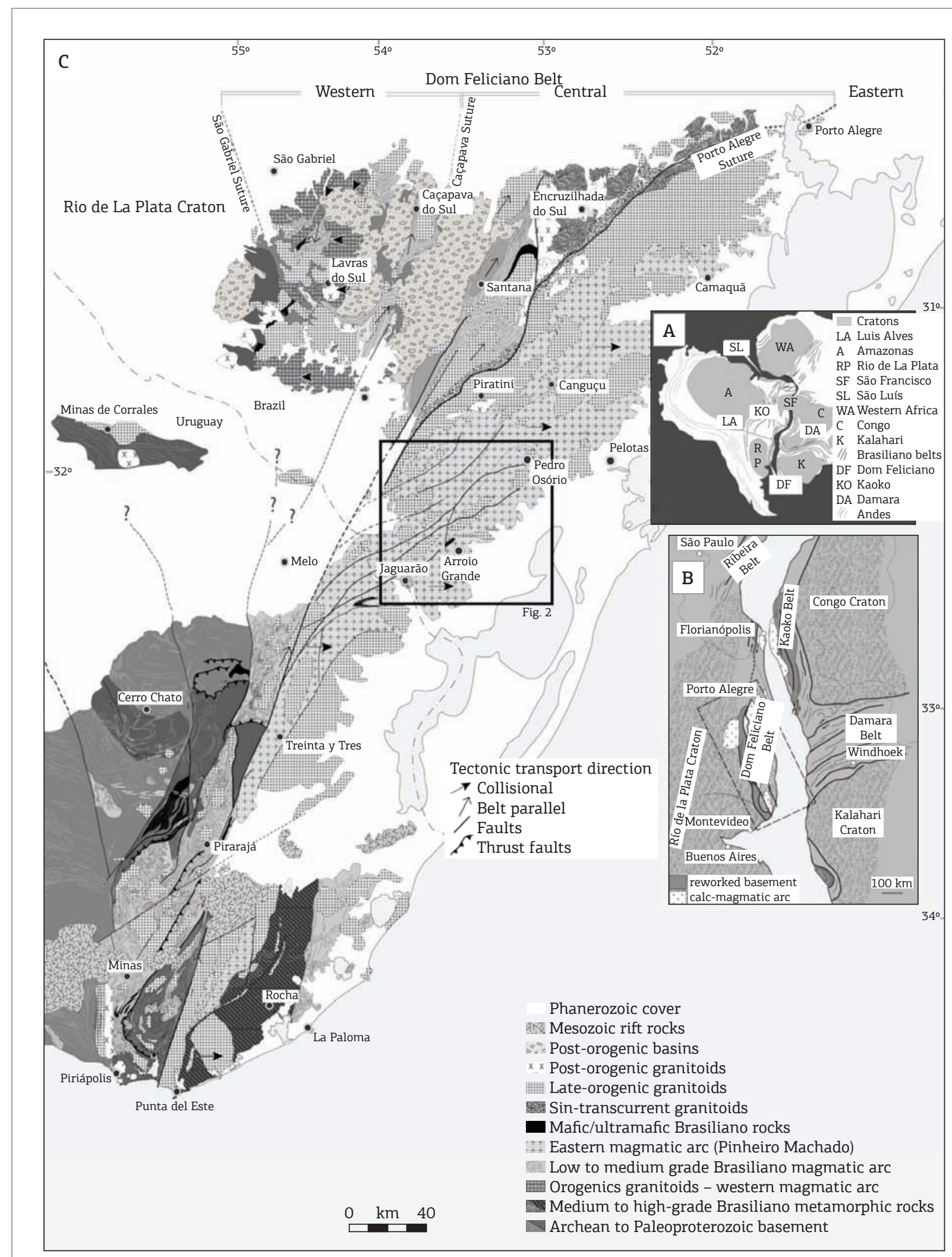

Figure 1. Lithotectonic map of Sul-rio-grandense and Uruguayan shields. (A) Gondwana configuration with main cratonic areas and belts related to Dom Feliciano Belt. (B) Localization of Dom Feliciano Belt and adjacent African belts in the Gondwana configuration. (C) Geological map of Dom Feliciano Belt and Río de La Plata Craton in South Brazil and Uruguay (modified from Lenz et al. 2013). 


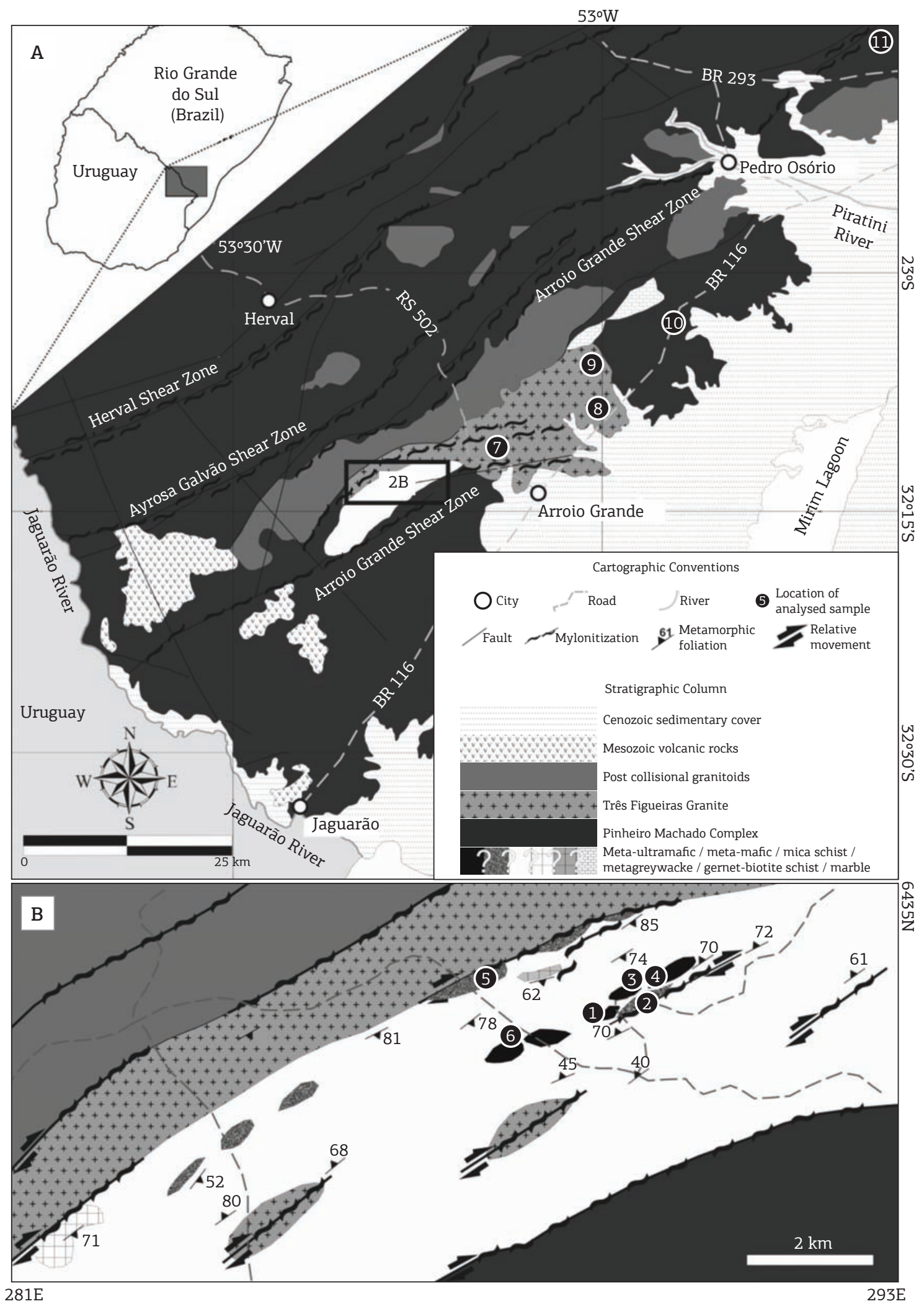

Figure 2. Geological map. (A) Southernmost Sul-rio-grandense Shield. (B) Detail of the southern area. Location of collected samples: (1) PU-1B, PU-1C and PU-1F. (2) PU-2B. (3) PU-3B and PU-3D. (4) PU-3E and PU-3F. (5) PU-20. (6) PU-49B. (7) PF-41D. (8) PF-43A. (9) PF-74C. (10) PF-47A. (11) PMB-2I and PMB-2F. 
The talc-serpentine schists are constituted by aggregates of talc and serpentine (both $\approx 50-70 \%$ ) and minor tremolite, clinochlore and disseminated chromite. The tremolitites are composed by $\approx 90 \%$ tremolite and subordinated clinochlore, talc and disseminated chromite. The chloritites are constituted by $\approx 95 \%$ clinochlore and minor ilmenite $(1-2 \%)$, zircon $(1-2 \%)$, serpentine and tremolite. One chloritite sample shows the presence of $\mathrm{Cr}$-chlorite (kämmererite or kotschubeite), detected in X-ray diffraction analysis. The chromites found in talc-serpentine schists and tremolitites (Fig. 3C) are anhedral, fine to medium grained $(<1-5 \mathrm{~mm})$. Stretching lineations are common, marked by cataclastic (pull-apart) textures. Chromite accumulations in layers or pods are not found.

The meta-mafic unit is represented by epidote amphibolites, metadiorites and metagabbros. The epidote amphibolites form NE-SW centimetric to decametric discontinuous elongated bodies (Fig. 3D), are fine grained and show millimetric irregular and discontinuous banding marked by quartz and plagioclase. The metadiorites and metagabbros are centimetric to metric, found as xenoliths within granitoids (Pinheiro Machado and Três Figueiras; Fig. 3E).

The epidote amphibolites are fine to medium grained, massive to foliated, mainly constituted by hornblende
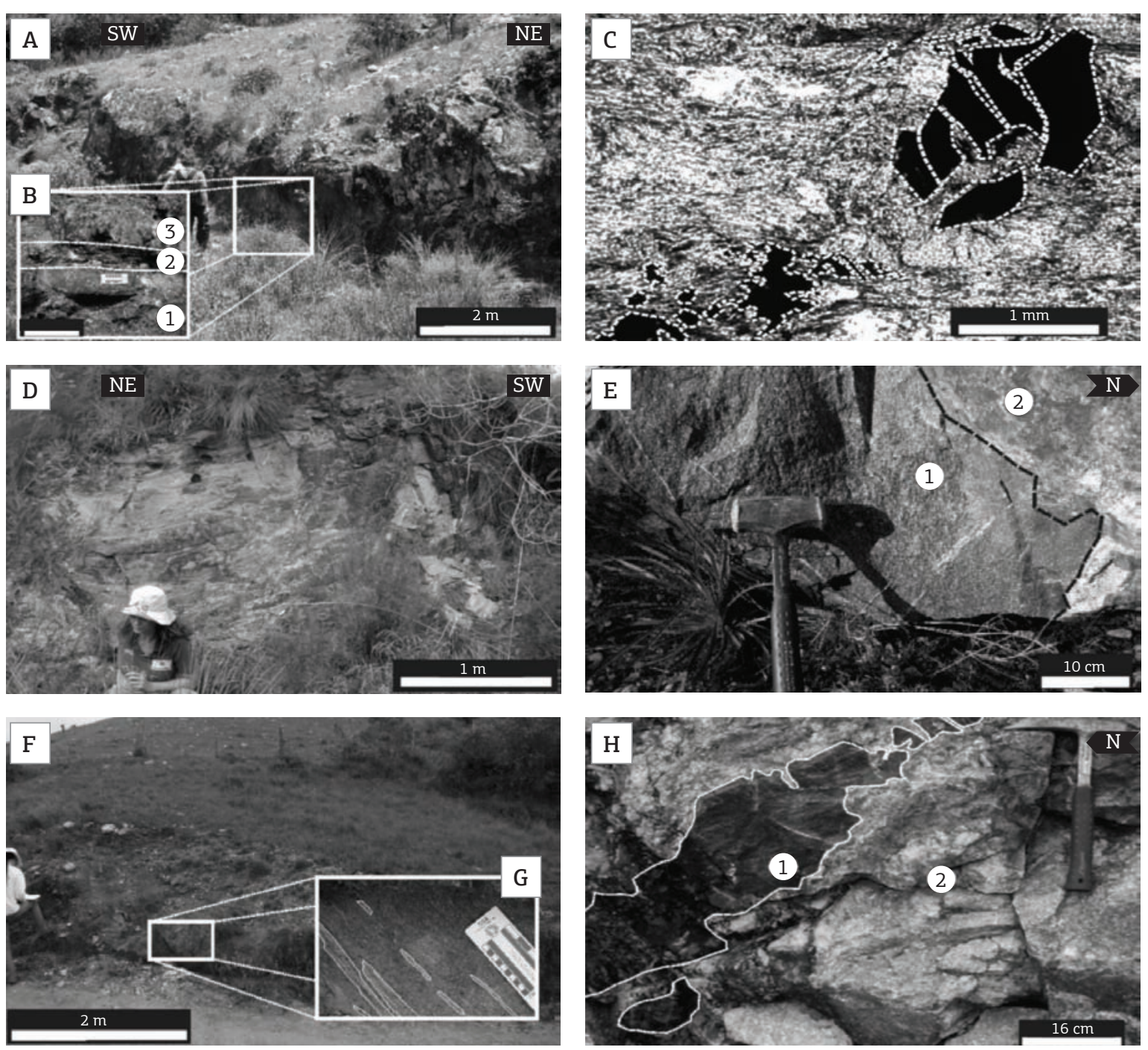

Figure 3. (A) Meta-ultramafic outcrop (location 4 in Fig. 2B). (B) Layers of (1) talc-serpentine schist (2) chloritite and (3) tremolitite. (C) Photomicrograph showing chromite grains with pull-apart texture in a matrix of talc and serpentine (talc-serpentine schist, sample PU-3B). (D) Epidote amphibolite outcrop (location 2 in Fig. 2B). (E) Xenolith of (1) metagabbro within (2) Pinheiro Machado Granite (location 11 in Fig. 2B). (F) Mica schist outcrop. (G) Detail of the outcrop showing lenses of quartzite parallel to the foliation of the schist. (H) (1) marble and (2) fragment of a deformed amphibolite dike. 
$(\approx 30-55 \%)$, plagioclase $(\approx 20-40 \%)$, epidote $(\approx 5-20 \%)$ and quartz $(\approx 5-10 \%)$, with minor biotite, chlorite, apatite, titanite and opaques. They show nematoblastic textures and paragenesis of epidote-amphibolite to amphibolite facies. The metadiorites and metagabbros are medium to coarse grained, massive to foliated, composed by green to brown hornblende $(\approx 40-50 \%)$, augite $(0-30 \%)$, plagioclase $(\approx 40 \%)$, quartz $(\approx 5-10 \%)$, and minor chlorite, biotite and disseminated pyrite and chalcopyrite. They occasionally show nematoblastic textures.

The metasedimentary unit is represented by mica schists, quartzites, metagreywackes, garnet-biotite schists and marbles. The mica schists form metric to kilometric bodies (Fig. $3 \mathrm{~F}$ ), associated with centimetric to metric quartzite lenses (Fig. 3G), and are also tectonically intercalated with granitoids (Pinheiro Machado and Três Figueiras), meta-ultramafic-mafic rocks, metagreywackes and garnet-biotite schists. They are also found as metric xenoliths within Três Figueiras granite. The marbles are metric to kilometric lenses bounded by granitoids (Pinheiro Machado Complex), with centimetric to decimetric calc-silicate reactions and amphibolite intercalations, cut by deformed amphibolite dikes (Fig. $3 \mathrm{H}$ ). The metagreywackes form metric to decametric bodies, generally found in contact with centimetric to metric folded leucogranitic veins.

The mica schists are fine to medium grained, constituted by quartz $(\approx 40 \%)$, muscovite $(\approx 25$ to $30 \%)$, biotite $(\approx 15 \%)$ and plagioclase $(\approx 15 \%)$, with predominantly lepidoblastic textures and paragenesis of greenschist facies. The quartzites are medium grained, massive to foliated, composed by quartz ( $\approx 80 \%)$ and minor feldspar, muscovite and tourmaline, with predominantly granoblastic textures. The metagreywackes are fine grained, massive, present quartz-feldspathic composition with a biotite + clay pseudomatrix (up to $50 \%$ ). The garnet-biotite schists are fine to medium grained, constituted by biotite $(\approx 40 \%)$, quartz $(\approx 30 \%)$, feldspar $(\approx 15 \%)$, garnet $(\approx 10 \%)$ and opaques, with predominantly lepidoblastic texture and amphibolite facies metamorphic paragenesis. The marbles are composed by calcite $(\approx 70 \%)$, diopside $(\approx 15 \%)$, and minor titanite and opaques $(\approx 5-10 \%)$, with predominantly granoblastic textures and paragenesis of hornblende hornfels facies.

Intense muscovitization and tourmalinization occur, related to the release of hydrothermal fluids by the cooling and emplacement of the Três Figueiras granite (Ramos \& Koester 2014). These hydrothermalites (muscovitites and tourmalinites) cross-cut Arroio Grande Ophiolitic Complex mica schists. The muscovitites form metric to decametric veins of monomineralic rock. The tourmalinites are massive or layered and form centimetric to metric lenses and veins, constituted by fine to medium grained tourmaline (schorlite-dravite group; $50-95 \%$ ), quartz, muscovite and biotite.

\section{MATERIALS AND METHODS}

Seventeen representative and less altered samples were collected in the outcrops marked in Fig. 2. All the meta-ultramafic samples were collected in the southern area of the studied complex, were the best outcrops are found (Fig. 2B - locations 1, 3, 4 and 6). The meta-mafic samples were collected in outcrops located in the southern area (Fig. 2B - sample PU-2B in location 2, and PU-20 in location 5), in xenoliths within Três Figueiras granite (Fig. 2A - sample PF-41D in location 7 , sample PF-43A in location 8 and sample PF-74C in location 9), and in the northern area (Fig. 2A-sample PF-47A). At the northeastern limit of the Ayrosa Galvão shear zone (Fig. 2 location 11), two metagabbro samples (PMB-2I and PMB-2F) were collected in xenoliths within Pinheiro Machado Complex granitoids in order to compare with the meta-mafics found further southwest in the main studied area.

Both meta-ultramafic and meta-mafic units were prepared in the Sample Preparation Laboratory at the Geosciences Institute, Rio Grande do Sul Federal University (Brazil). The samples were crushed and pulverized in a hydraulic press and in an agate grinding mill. After the preparation, they were analyzed in Acme Analytical Laboratories Ltd. (Canada) for whole rock geochemical data (packages 4A and $4 \mathrm{~B}$ - whole rock major, minor and trace elements). The major and trace elements were analyzed by Inductively Coupled Plasma Optical Emission Spectrometry and the rare earth elements (REE), by Inductively Couple Plasma Mass Spectrometry. The loss on ignition (LOI) was determined by heating the powdered samples for 60 minutes at $1,000^{\circ} \mathrm{C}$.

\section{LITHOGEOCHEMISTRY}

This section presents the results of the lithogeochemical analyses (Tables 1 and 2), as well as their discussion and interpretation. Major and minor elements are expressed as oxide weight percentages ( $\mathrm{wt} \%$ ). The trace elements are expressed as parts per million (ppm) and total iron, as $\mathrm{Fe}_{2} \mathrm{O}_{3}{ }^{*}$.

The meta-ultramafics have $\mathrm{SiO}_{2}$ contents between 25.51 and $59.68 \mathrm{wt} \%$. The enrichment in silica is directly related to the increase of talc content, reflecting its mineral composition $\left(\approx 63 \% \mathrm{SiO}_{2}\right)$. The chlorite-rich samples show low $\mathrm{SiO}_{2}$ values, reflecting the chemical composition of this mineral $\left(\approx 30 \% \mathrm{SiO}_{2}\right)$. The same relationship is seen for $\mathrm{Al}_{2} \mathrm{O}_{3}, \mathrm{Fe}_{2} \mathrm{O}_{3}$, and $\mathrm{MnO}$ contents, which also reflect the chlorite chemistry. The $\mathrm{MgO}$ concentration does not show great variation (22.93 to $28.98 \mathrm{wt} \%$ ) and the talc-rich samples show the highest values. The $\mathrm{Rb}$ (average $1.8 \mathrm{ppm}$ ), Co (average $68.5 \mathrm{ppm}$ ), $\mathrm{V}$ (average $67 \mathrm{ppm}$ ), $\mathrm{U}$ and Th (average 0.05 and $0.02 \mathrm{ppm}$, respectively, not including the chloritites, which have anomalous contents influenced by the presence of zircon), and the elevated $\mathrm{Cr}$ and 
Table 1. Whole rock composition of representative samples from the meta-ultramafic unit.

\begin{tabular}{|c|c|c|c|c|c|c|c|c|c|}
\hline Sample & PU-1B & PU-1C & PU-1F & PU-3B & PU-49B & AP-23B & PU-3D & PU-3E & PU-3F \\
\hline Rock & $\begin{array}{l}\text { talc-serpentine } \\
\text { schist }\end{array}$ & $\begin{array}{l}\text { talc-serpentine } \\
\text { schist }\end{array}$ & $\begin{array}{l}\text { talc-serpentine } \\
\text { schist }\end{array}$ & $\begin{array}{l}\text { talc-serpentine } \\
\text { schist }\end{array}$ & $\begin{array}{l}\text { talc-serpentine } \\
\text { schist }\end{array}$ & tremolitite & tremolitite & chloritite & chloritite \\
\hline $\mathrm{SiO}_{2}$ & 59.44 & 59.10 & 59.68 & 58.23 & 54.50 & 35.71 & 36.26 & 25.51 & 35.39 \\
\hline $\mathrm{Al}_{2} \mathrm{O}_{3}$ & 0.90 & 1.41 & 0.83 & 1.66 & 2.72 & 15.05 & 14.34 & 20.37 & 15.30 \\
\hline $\mathrm{Fe}_{2} \mathrm{O}_{3}{ }^{*}$ & 4,79 & 5,67 & 5.73 & 4,57 & 5,65 & 10,69 & 10,90 & 14,90 & 10,80 \\
\hline $\mathrm{MnO}$ & 0.05 & 0.08 & 0.05 & 0.03 & 0.08 & 0.10 & 0.15 & 0.18 & 0.13 \\
\hline $\mathrm{MgO}$ & 28.53 & 27.20 & 26.76 & 28.98 & 24.13 & 25.37 & 23.11 & 24.24 & 22.93 \\
\hline $\mathrm{CaO}$ & 0.17 & 0.20 & 0.17 & 0.07 & 6.16 & 3.16 & 3.49 & 0.01 & 1.99 \\
\hline $\mathrm{Na}_{2} \mathrm{O}$ & 0.02 & 0.15 & 0.10 & 0.04 & 0.08 & 0.02 & 0.14 & - & 0.07 \\
\hline $\mathrm{K}_{2} \mathrm{O}$ & - & 0.14 & 0.04 & 0.02 & 0.09 & - & 0.08 & - & 0.05 \\
\hline $\mathrm{TiO}_{2}$ & 0.02 & 0.02 & 0.04 & 0.02 & 0.06 & 0.21 & 0.32 & 3.20 & 0.90 \\
\hline $\mathrm{P}_{2} \mathrm{O}_{5}$ & - & 0.01 & 0.02 & 0.02 & 0.03 & - & 0.01 & 0.11 & 0.02 \\
\hline LOI & 5.1 & 5.5 & 5.6 & 5.8 & 6.1 & 8.9 & 10.4 & 10.5 & 11.9 \\
\hline Total & 99,02 & 99,48 & 99.02 & 99,44 & 99,60 & 99,21 & 99,23 & 99,02 & 99,48 \\
\hline Sc & 3 & 7 & 4 & 2 & 9 & 6 & 13 & 38 & 22 \\
\hline $\mathrm{Be}$ & - & 2 & - & - & - & 1 & - & 3 & 5 \\
\hline $\mathrm{V}$ & 18 & - & 37 & - & 37 & 87 & 141 & 159 & 124 \\
\hline $\mathrm{Cr}$ & 1923 & 1560 & 1841 & 1765 & 1930 & 1505 & 2880 & 403 & 1184 \\
\hline Co & 67.3 & 65.6 & 70.9 & 74.5 & 24.8 & 75.0 & 69.0 & 86.2 & 83.3 \\
\hline $\mathrm{Ni}$ & 1595 & 1536 & 1508 & 1845 & 490 & 1127 & 1812 & 1005 & 1567 \\
\hline $\mathrm{Cu}$ & 1.0 & 2.3 & 6.6 & 0.6 & 35.7 & 36.6 & 7.1 & 10.2 & 3.7 \\
\hline $\mathrm{Zn}$ & 6 & 13 & 7 & 11 & 36 & 32 & 86 & 33 & 91 \\
\hline $\mathrm{Ga}$ & 1.1 & 3.7 & 1.6 & 2.8 & 4.4 & 20.0 & 21.8 & 23.5 & 23.6 \\
\hline $\mathrm{Rb}$ & - & 4.0 & 2.9 & 1.1 & 3.3 & 0.4 & 2.4 & 0.1 & 2.1 \\
\hline $\mathrm{Sr}$ & 0.6 & 1.2 & 11.8 & 2.1 & 15.5 & 3.6 & 12.1 & 3.9 & 8.9 \\
\hline $\mathrm{Y}$ & 6.8 & 1.3 & 1.3 & 0.2 & 3.4 & 2.8 & 11.4 & 297.0 & 34.2 \\
\hline $\mathrm{Zr}$ & 0.5 & 3.7 & 4.3 & 1.0 & 7.1 & 1.8 & 8.5 & 866.6 & 222.6 \\
\hline $\mathrm{Nb}$ & - & 0.7 & 0.3 & 0.8 & 1.0 & 1.7 & 4.8 & 43.6 & 10.8 \\
\hline Mo & - & - & - & - & 0.1 & - & - & - & - \\
\hline $\mathrm{Sn}$ & - & - & - & - & - & - & - & - & 1 \\
\hline Cs & - & - & - & 0.2 & 0.1 & - & 0.2 & - & 0.2 \\
\hline $\mathrm{Ba}$ & - & 2 & 11 & 3 & 7 & 2 & 35 & 10 & 11 \\
\hline $\mathrm{La}$ & 10.1 & 1.4 & 1.7 & 0.5 & 5.2 & 1.4 & 4.9 & 413.0 & 26.4 \\
\hline $\mathrm{Ce}$ & 3.2 & 2.3 & 1.5 & 0.4 & 12.5 & 2.0 & 16.5 & 252.8 & 30.3 \\
\hline $\operatorname{Pr}$ & 2.78 & 0.35 & 0.27 & 0.05 & 1.12 & 0.30 & 1.25 & 94.43 & 5.94 \\
\hline $\mathrm{Nd}$ & 10.7 & 1.5 & 1.1 & - & 5.3 & 1.5 & 5.7 & 350.9 & 25.1 \\
\hline $\mathrm{Sm}$ & 2.00 & 0.32 & 0.27 & 0.06 & 0.86 & 0.21 & 1.22 & 65.22 & 4.90 \\
\hline $\mathrm{Eu}$ & 0.51 & 0.05 & 0.07 & - & 0.23 & 0.12 & 0.39 & 15.30 & 1.05 \\
\hline $\mathrm{Gd}$ & 1.59 & 0.26 & 0.26 & - & 0.91 & 0.29 & 1.38 & 57.51 & 5.73 \\
\hline $\mathrm{Tb}$ & 0.26 & 0.03 & 0.05 & - & 0.10 & 0.05 & 0.22 & 8.78 & 0.88 \\
\hline Dy & 1.65 & 0.38 & 0.25 & 0.13 & 0.90 & 0.32 & 1.81 & 54.14 & 6.45 \\
\hline Ho & 0.29 & 0.04 & 0.06 & - & 0.11 & 0.11 & 0.36 & 11.27 & 1.22 \\
\hline $\mathrm{Er}$ & 0.67 & 0.15 & 0.18 & 0.03 & 0.37 & 0.26 & 0.99 & 32.79 & 3.35 \\
\hline $\mathrm{Tm}$ & 0.14 & 0.02 & 0.03 & - & 0.07 & 0.04 & 0.19 & 4.56 & 0.56 \\
\hline $\mathrm{Yb}$ & 0.87 & 0.14 & 0.16 & 0.08 & 0.58 & 0.20 & 1.29 & 29.16 & 3.32 \\
\hline $\mathrm{Lu}$ & 0.12 & 0.02 & 0.03 & - & 0.07 & 0.04 & 0.17 & 4.39 & 0.44 \\
\hline $\mathrm{Hf}$ & - & - & - & - & 0.2 & - & 0.2 & 22.0 & 5.2 \\
\hline $\mathrm{Ta}$ & - & - & - & - & - & - & 0.1 & 3.0 & 0.5 \\
\hline $\mathrm{W}$ & - & 0.9 & - & 0.9 & 1.7 & - & - & 1.0 & 2.9 \\
\hline $\mathrm{Tl}$ & - & - & - & - & - & - & 0.1 & - & - \\
\hline $\mathrm{Pb}$ & - & 0.6 & 0.7 & - & 1.5 & 0.4 & 0.6 & 4.9 & 2.4 \\
\hline $\mathrm{Bi}$ & 0.3 & 0.3 & 1.4 & - & 1.7 & 0.2 & 0.1 & - & - \\
\hline Th & - & - & 0.2 & - & 0.5 & - & 0.7 & 50.2 & 10.4 \\
\hline $\mathrm{U}$ & - & - & 0.2 & - & - & 0.2 & - & 4.1 & 1.3 \\
\hline
\end{tabular}


Table 2. Whole rock composition of representative samples from the meta-mafic unit.

\begin{tabular}{|c|c|c|c|c|c|c|c|c|}
\hline Sample & PF-43A & PF-41D & PF-74C & PMB-2I & PMB-2F & PF-47A & PU-2B & PU-20 \\
\hline Rock & metadiorite & metagabbro & metagabbro & metagabbro & metaggabro & $\begin{array}{c}\text { epidote } \\
\text { amphibolite }\end{array}$ & $\begin{array}{c}\text { epidote } \\
\text { amphibolite }\end{array}$ & $\begin{array}{c}\text { epidote } \\
\text { amphibolite }\end{array}$ \\
\hline $\mathrm{SiO}_{2}$ & 55.75 & 50.89 & 40.74 & 49.14 & 47.93 & 49.13 & 47.61 & 51.40 \\
\hline $\mathrm{Al}_{2} \mathrm{O}_{3}$ & 13.89 & 15.35 & 15.41 & 15.11 & 15.05 & 14.78 & 15.06 & 15.70 \\
\hline $\mathrm{Fe}_{2} \mathrm{O}_{3}{ }^{*}$ & 6.89 & 8.45 & 17.84 & 11.19 & 11.29 & 8.98 & 11.73 & 11.58 \\
\hline $\mathrm{MnO}$ & 0.11 & 0.14 & 0.18 & 0.19 & 0.19 & 0.15 & 0.18 & 0.18 \\
\hline $\mathrm{MgO}$ & 8.01 & 9.37 & 6.99 & 7.58 & 8.43 & 8.93 & 6.49 & 5.60 \\
\hline $\mathrm{CaO}$ & 6.27 & 7.86 & 12.64 & 8.33 & 8.89 & 7.93 & 13.54 & 9.14 \\
\hline $\mathrm{Na}_{2} \mathrm{O}$ & 2.58 & 2.55 & 0.78 & 2.80 & 2.82 & 1.17 & 1.81 & 3.12 \\
\hline $\mathrm{K}_{2} \mathrm{O}$ & 2.03 & 1.67 & 0.88 & 2.17 & 1.96 & 3.59 & 0.27 & 0.26 \\
\hline $\mathrm{TiO}_{2}$ & 0.68 & 0.88 & 1.93 & 1.35 & 1.10 & 0.65 & 1.64 & 1.18 \\
\hline $\mathrm{P}_{2} \mathrm{O}_{5}$ & 0.18 & 0.18 & 0.11 & 0.15 & 0.21 & 0.08 & 0.15 & 0.06 \\
\hline LOI & 3.3 & 2.4 & 2.1 & 1.7 & 1.8 & 4.3 & 1.3 & 1.5 \\
\hline Total & 99.69 & 99.64 & 99.60 & 99.71 & 99.69 & 99.69 & 99.78 & 99.73 \\
\hline Sc & 17 & 21 & 47 & 27 & 26 & 29 & 40 & 40 \\
\hline $\mathrm{Be}$ & 2 & 2 & - & - & - & - & - & 1 \\
\hline V & 126 & 171 & 690 & 328 & 270 & 199 & 272 & 265 \\
\hline $\mathrm{Cr}$ & 609 & 609 & 21 & 369 & 356 & 513 & 267 & 404 \\
\hline Co & 31.5 & 38.7 & 69.0 & 44.5 & 48.0 & 40.6 & 49.8 & 47.3 \\
\hline $\mathrm{Ni}$ & 225 & 241 & 12 & 102 & 116 & 178 & 137 & 117 \\
\hline $\mathrm{Cu}$ & 14.2 & 41.5 & 195.7 & 15.2 & 8.3 & 8.4 & 63.0 & 30.3 \\
\hline $\mathrm{Zn}$ & 54 & 39 & 50 & 72 & 66 & 70 & 18 & 39 \\
\hline $\mathrm{Ga}$ & 15.0 & 15.2 & 19.8 & 23.2 & 20.2 & 15.4 & 16.1 & 13.9 \\
\hline $\mathrm{Rb}$ & 95.9 & 56.6 & 31.2 & 138.9 & 121.7 & 161.8 & 2.8 & 10.2 \\
\hline $\mathrm{Sr}$ & 505.4 & 480.4 & 558.6 & 381.8 & 472.9 & 186.3 & 136.6 & 74.2 \\
\hline $\mathrm{Y}$ & 17.7 & 18.9 & 20.9 & 24.7 & 21.6 & 16.7 & 27.1 & 25.7 \\
\hline $\mathrm{Zr}$ & 145.8 & 126.2 & 43.3 & 119.0 & 103.6 & 75.7 & 107.8 & 61.0 \\
\hline $\mathrm{Nb}$ & 6.1 & 6.1 & 3.6 & 9.0 & 4.9 & 2.4 & 5.3 & 2.6 \\
\hline Mo & 0.5 & 0.5 & 0.2 & 0.8 & 0.2 & 0.4 & - & 0.1 \\
\hline $\mathrm{Sn}$ & - & - & 2 & 3 & 1 & - & 2 & - \\
\hline Cs & 6.6 & 3.9 & 2.8 & 7.9 & 5.5 & 8.9 & 0.1 & 0.4 \\
\hline $\mathrm{Ba}$ & 435 & 364 & 197 & 287 & 289 & 668 & 34 & 66 \\
\hline $\mathrm{La}$ & 29.4 & 23.9 & 12.4 & 20.0 & 16.8 & 9.1 & 5.2 & 4.7 \\
\hline $\mathrm{Ce}$ & 59.4 & 48.3 & 29.9 & 51.9 & 38.6 & 15.2 & 13.8 & 11.2 \\
\hline $\operatorname{Pr}$ & 6.53 & 5.40 & 4.46 & 6.81 & 5.28 & 2.20 & 2.22 & 1.70 \\
\hline $\mathrm{Nd}$ & 25.5 & 22.0 & 20.4 & 28.2 & 25.2 & 9.4 & 12.0 & 8.6 \\
\hline Sm & 4.74 & 4.51 & 4.23 & 6.38 & 5.64 & 2.07 & 3.48 & 2.85 \\
\hline $\mathrm{Eu}$ & 1.19 & 1.29 & 1.20 & 1.70 & 1.53 & 0.70 & 1.27 & 1.00 \\
\hline Gd & 4.20 & 4.00 & 4.39 & 6.28 & 5.29 & 2.39 & 4.45 & 3.83 \\
\hline $\mathrm{Tb}$ & 0.55 & 0.56 & 0.66 & 0.79 & 0.70 & 0.39 & 0.78 & 0.70 \\
\hline Dy & 3.44 & 3.22 & 3.93 & 5.50 & 4.19 & 2.80 & 5.32 & 4.76 \\
\hline Ho & 0.66 & 0.64 & 0.83 & 0.91 & 0.69 & 0.54 & 0.99 & 0.99 \\
\hline $\mathrm{Er}$ & 1.68 & 1.78 & 2.37 & 2.47 & 2.00 & 1.75 & 3.58 & 3.06 \\
\hline $\mathrm{Tm}$ & 0.24 & 0.28 & 0.35 & 0.36 & 0.29 & 0.26 & 0.44 & 0.44 \\
\hline $\mathrm{Yb}$ & 1.57 & 1.59 & 2.11 & 2.37 & 1.73 & 1.66 & 2.65 & 2.76 \\
\hline $\mathrm{Lu}$ & 0.21 & 0.23 & 0.30 & 0.37 & 0.26 & 0.26 & 0.42 & 0.44 \\
\hline $\mathrm{Hf}$ & 3.9 & 3.2 & 1.6 & 4.1 & 3.1 & 1.8 & 3.0 & 1.9 \\
\hline Ta & 0.4 & 0.5 & 0.3 & 0.5 & 0.3 & 0.1 & 0.5 & 0.1 \\
\hline $\mathrm{W}$ & - & 1.0 & 0.5 & 0.6 & - & 0.7 & - & - \\
\hline $\mathrm{Tl}$ & 0.4 & 0.3 & - & 0.8 & 0.7 & 0.8 & - & - \\
\hline $\mathrm{Pb}$ & 1.9 & 2.1 & 1.3 & 2.0 & 2.0 & 1.2 & 0.2 & 0.4 \\
\hline $\mathrm{Bi}$ & - & - & - & 0.1 & 0.1 & - & - & - \\
\hline Th & 6.0 & 3.4 & 1.0 & 5.7 & 2.2 & 2.2 & 0.3 & 0.4 \\
\hline $\mathrm{U}$ & 0.7 & 0.6 & 0.2 & 5.4 & 0.6 & 0.8 & - & - \\
\hline
\end{tabular}

LOI: loss on ignition. 
Ni contents (average 1,666 and 1,387 ppm respectively) are consistent with peridotites (upper mantle or crustal cumulates) (Coleman 1977; Wilson 1989) and discard a possible sedimentary origin (e.g. dolomites and dolomitic marls).

In general, the meta-mafics have major element composition consistent with the average oceanic basalt composition of Metcalf and Shervais (2008). Average Cr, Ni, V, Co and $\mathrm{Zr}$ contents are consistent with gabbroic and basaltic compositions of Coleman (1977).

\section{Element mobility}

Due to mobility during metamorphic, hydrothermal and weathering processes, the relationship of the elements with the LOI (which reflects the volatile content of the samples) was investigated. The meta-ultramafics show high LOI values (5.1 $11.9 \mathrm{wt} \%)$, indicating large content of hydrated phases. The meta-mafics have lower LOI values (1.3 - $4.3 \mathrm{wt} \%)$.

In major and minor elements versus LOI diagrams (Fig. 4), the meta-ultramafics show negative $\mathrm{SiO}_{2}$ and positive $\mathrm{Al}_{2} \mathrm{O}_{3}$, $\mathrm{Fe}_{2} \mathrm{O}_{3}{ }^{*}$ and $\mathrm{MnO}$ correlations. It represents chloritization and tremolitization processes, that increase especially water and $\mathrm{Al}_{2} \mathrm{O}_{3}$ contents and decrease the silica content of the rocks. Sample PU-49 (talc-serpentine schist) has the higher $\mathrm{LOI}$ and $\mathrm{CaO}$ contents, possibly indicating the presence of carbonate. The meta-mafics show positive $\mathrm{MgO}$ and $\mathrm{K}_{2} \mathrm{O}$ and negative $\mathrm{CaO}, \mathrm{MnO}$ and $\mathrm{TiO}_{2}$ correlations with $\mathrm{LOI}$ (Fig. 4), possibly indicating the transformation of augite in hornblende, biotite and chlorite, which is consistent with thin section observations.

In trace elements versus LOI diagrams (Fig. 4), the meta-ultramafic samples show a positive $V$ correlation that could represent the formation of magnetite and ilmenite during hydration. The meta-mafics show positive $\mathrm{Cr}, \mathrm{Ba}$ and $\mathrm{Rb}$ correlations with LOI (Fig. 4) and may represent the formation of biotite.

In Figure 5A (REE + Y diagram), the talc-serpentine schists do not show relationship between LOI and the enrichment in these elements. They show an increase in light REE of $2-30$ times chondritic values, and in heavy REE of $1-6$ times (except 1 sample that is depleted in all REE, barring La). On the other hand, the tremolitites and chloritites show a clear relationship between LOI and the enrichment in REE + Y (Fig. 5B). The tremolitites have $6-11$ times chondritic values to light REE and $2-7$ times to heavy REE. The chloritites show higher enrichments: $100-1,100$ times to light REE and $20-110$ to heavy REE. These contents, much higher than the chondrite and also higher than the expected for serpentinites, suggest interaction with external fluid sources and an overlay of REE values caused by metasomatic processes subsequent to the protoliths serpentinization (Paulick et al. 2006).

Although varying in the contents, the REE distribution patterns of all meta-ultramafic samples show similar shapes, indicating a common source. The patterns ranging from slightly concave to flat in the middle and heavy REE are similar to the serpentinites derived from oceanic peridotites and those infiltrated by basaltic melts of Peltonen and Kontinen (2004). The negative $\mathrm{Ce}$ and Eu anomalies may indicate hydrothermal interactions, weathering and serpentinization, all of them caused by oceanic waters (D'Orazio et al. 2004; Spandler et al. 2008; De Hoog et al. 2009).

The meta-mafic samples do not show evident relationship between REE and LOI contents (Fig. 5C). The light REE vary from 20 to 100 times chondritic values. The heavy REE show a relatively flat pattern, without great variation (8 to 20 times chondritic values).

\section{Tectonic environments}

Chemical modifications caused by serpentinization and subsequent metasomatism, together with the absence of relict igneous minerals or textures, make it difficult to define clearly the protoliths of the meta-ultramafics and their tectonic environment of formation on the basis of the available data. However, some considerations can be made. As already discussed in Lithogeochemistry section, the high $\mathrm{Cr}$ and $\mathrm{Ni}$ contents of these rocks point to a peridotite protolith (upper mantle or crustal ultramafic cumulate). In the $\mathrm{Cr}$ versus Ni diagram (Fig. 5D), the samples plot in the ophiolitic cumulates and associated mantle-derived ultramafic rocks field, except for one talc schist sample, which has lower Ni content. All meta-ultramafic samples (except the chloritites, which have anomalous Zr contents) plot in the ocean floor peridotite field of Fig. 5E.

The less altered and less modified meta-mafic samples provided a large amount of clues about the tectonic environments in which their protoliths may have been formed. The $\mathrm{Zr}, \mathrm{P}_{2} \mathrm{O}_{5}$, $\mathrm{Nb}$ and $\mathrm{Y}$ contents indicate a tholeiitic (oceanic) chemical affinity (Fig. 5F). In Figs. 5G and 5H diagrams, the samples plot in the mid-ocean ridge basalts (MORB) fields (except sample PF-47A, which has lower Y content; Fig. 5H). The MORB field of Fig. 5H includes back-arc basin basalts (Pearce et al. 1984). Sample PF-74C plots in the volcanic arc (Fig. 5G) and arc tholeiites (Fig. 5H).

In the $\mathrm{MgO} / \mathrm{TiO}_{2}$ versus $\mathrm{Zr}$ diagram (Fig. 5I), samples PF-74C and PU-20 plot in the primitive or evolved island arc gabbro field. All other samples plot in the normal mid-ocean ridge (MOR) (cumulate) gabbro field.

In the Th-Ta-Hf /3 diagram (Fig. 5J), most of the samples plot in the supra-subduction zone (SSZ) (i.e. The region above an active subduction zone like forearcs, back-arcs and volcanic arcs) basalts field, with exception of one epidote amphibolite sample (PU-2B), which plots in the enriched MORB (E-MORB) field (this field also includes back-arc basin basalts with no detectable subduction component; Pearce et al. 1984). According to Hawkins (2003), the adittion of sediments in the magma source, expected in a subduction zone setting, shifts the composition toward the Th apex of the diagram. 

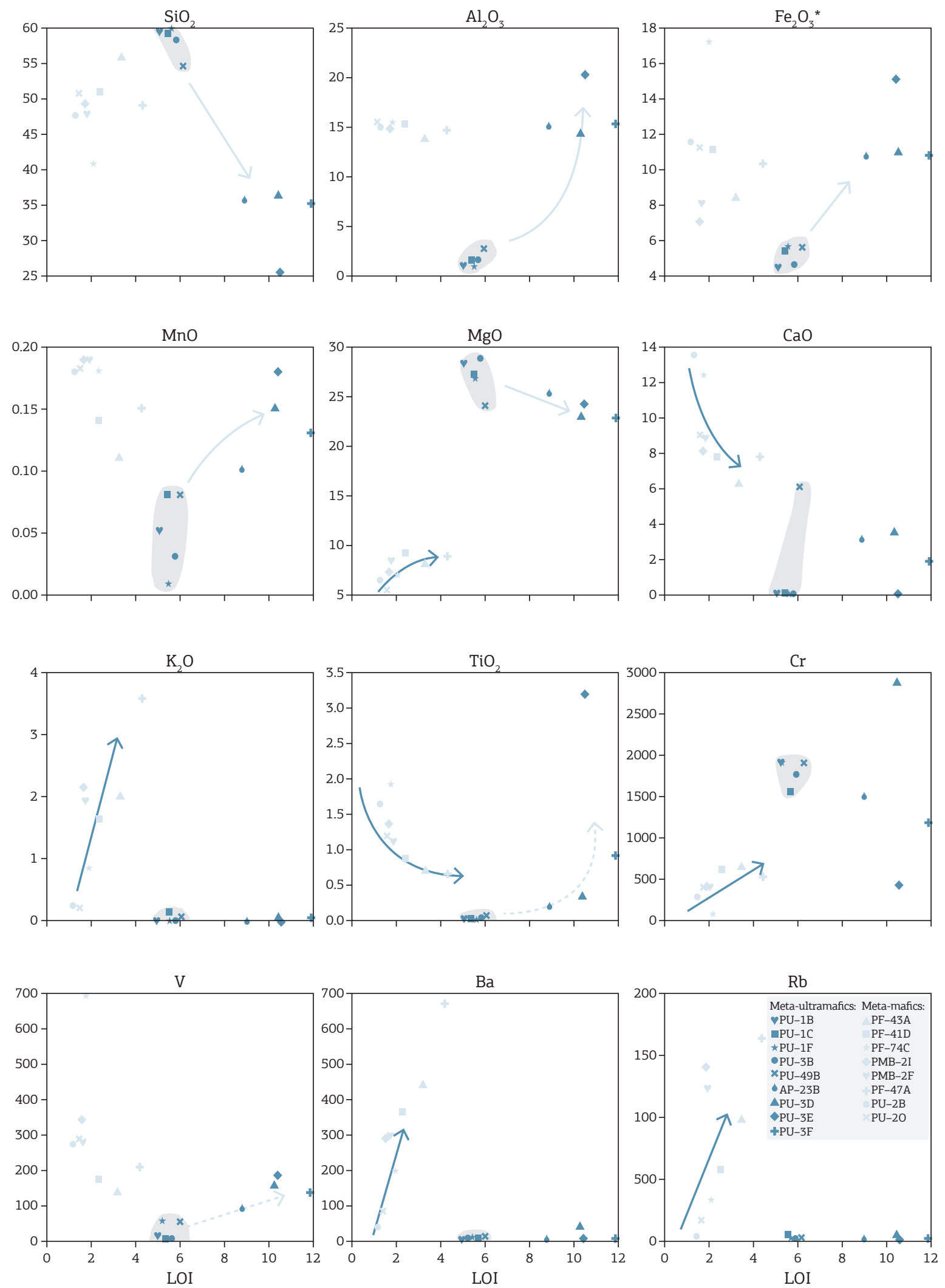

Grey field: talc-serpentine schists; grey arrow: tremolitization and chloritization; grey dotted arrow: ilmenite formation; black arrow: transformation of augite/hornblende in biotite/chlorite.

Figure 4. Bivariate diagrams of major, minor and trace elements versus loss on ignition. 


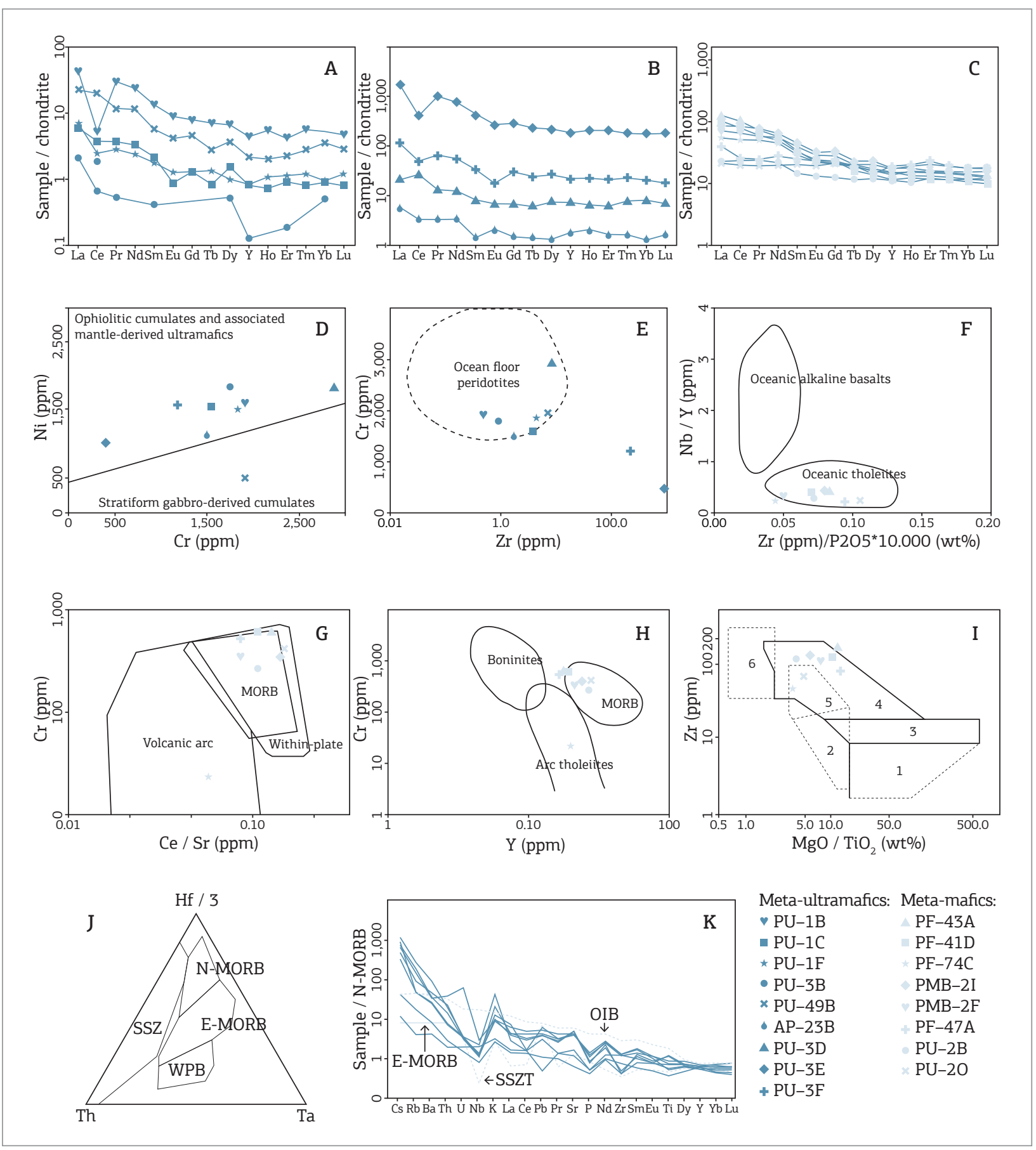

Figure 5. (A) Chondrite normalized (McDonough and Sun 1995) REE + Y diagrams to the talc-serpentine schist samples. (B) Tremolitite and chloritite samples. (C) Meta-mafic samples. (D) $\mathrm{Cr}$ versus Ni classification diagram, discrimination between mantle- or gabbro-derived cumulates (modified from Floyd et al. 2000). (E) $\mathrm{Zr}$ versus $\mathrm{Cr}$ classification diagram (Splander et al. 2008). (F) $\mathrm{Zr} / \mathrm{P}_{2} \mathrm{O}_{5}{ }^{*} 10000$ versus $\mathrm{Nb} / \mathrm{Y}$ diagram, tholeiitic or alkaline affinity for oceanic basalts (modified from Floyd \& Winchester 1975). (G) Ce/Sr versus $\mathrm{Cr}$ diagram, discrimination between basalts (modified from Pearce 1982). MORB: mid-ocean ridge basalts. $(\mathrm{H}) \mathrm{Y}$ versus $\mathrm{Cr}$ diagram, discrimination between basalts (modified from Dilek et al. 2007). (I) $\mathrm{MgO} / \mathrm{TiO}_{2}$ versus $\mathrm{Zr}$ ocean-floor related gabbros diagram, discrimination between (1) primitive mid-ocean ridge (MOR) gabbros, (2) primitive island-arc gabbros, (3) primitive MOR (cumulate) gabbros and normal MOR (cumulate) gabbros, (4) normal MOR (cumulate) gabbros, (5) primitive island-arc gabbros and evolved island-arc gabbros, (6) ocean island cumulate gabbros (modified from Biermanns 1996). (J) Th-Ta-Hf/3 ternary diagram (modified from Wood et al. 1981), N-MORB: normal MORB; E-MORB: enriched MORB; WPB: within-plate basalts; SSZ: supra-subduction zone. (K) N-MORB normalized (Sun \& McDonough 1989) spidergram: average ocean island basalts (OIB), E-MORB and supra-subduction zone tholeiites (SSZT) from Metcalf and Shervais (2008). 
In the normal MORB (N-MORB) normalized spidergram (Fig. 5K), the zigzag REE patterns are typical of supra-subduction zone, where subducting slab-derived elements (Cs, Rb, $\mathrm{Ba}, \mathrm{Th}, \mathrm{U}, \mathrm{K}, \mathrm{La}, \mathrm{Ce}, \mathrm{Pb}, \mathrm{Sr}$ ) superimpose that of the mantle wedge (Nb, Zr, Sm, Eu, Ti, Dy, Y, Yb, Lu). The sample PU-2B is an exception, showing a pattern similar to the E-MORB. The same occurs with the $\mathrm{Pb}$ anomalies: the $\mathrm{PU}-2 \mathrm{~B}$ sample shows $\mathrm{Pb}$ negative anomaly, typical of MORB, while all the other samples show positive $\mathrm{Pb}$ anomalies (and also Ce negative anomalies), which suggests influence of sediments in the magma composition in a subduction zone setting (Hawkesworth et al. 1993; Marini et al. 2005; Godard et al. 2006; Metcalf \& Shervais 2008).

The high $\mathrm{Ce} / \mathrm{Pb}(>10)$ ratios of all meta-mafics indicate a MORB affinity (Plank 2005). To $\mathrm{Pb} / \mathrm{Ce}$ ratios, the typical MORB value is $\approx 0.04$ and all the samples show this feature, except PF-47A and PMB-02F samples, which have higher values suggesting contamination of the mantle source by crustal material and fluid flux in a subduction zone setting (Porter \& White 2003; Rollinson 2007). The La/Nb and Th/La ratios (ranging from MORB to sediment-contaminated basaltic magmas) together with $\mathrm{Sr} / \mathrm{Nd}$ ratios (indicating enrichment of the magma source caused by oceanic waters and subduction zone-derived fluids) seem to reinforce the above assumption (Thompson et al. 1984; McDonough \& McCulloch 1987; Metcalf et al. 2000; Plank 2005; Koglin et al. 2009).

Both MORB and back-arc basin basalts share geochemical features mainly when the spreading center of the basin is distal from the subduction zone (Pearce et al. 1984; Hawkins 2003; Pearce \& Stern 2006; Metcalf \& Shervais 2008; Dilek $\&$ Furnes 2011). The meta-mafic samples concomitantly show a MORB signature and the influence of subduction components, which suggests, in the proposed suprasubduction zone model, that the back-arc basin region is the most suitable tectonic environment of formation of the epidote amphibolite, metadiorite and metagabbro protoliths. According to Hawkins (2003), the vast majority of MORB geochemical signatures found in ophiolites represents oceanic crust formed in a back-arc basin setting.

\section{Metasomatism of former serpentinite bodies}

On the basis of the available data, it is not possible to define precisely yet if the metasomatism of former serpentinite bodies, responsible for the formation of talc-, tremolite- and chlorite-rich zones, occurred after their incorporation into the orogenic belt or in the ocean floor. In orogenic belts, metasomatism is common in the contact of ultramafic bodies and the country rocks (usually quartz-feldspathic) in regional metamorphic terrains, a set where silica-rich fluids migrate from the country rocks to the ultramafics, often generating virtually monomineralic metasomatic zones around the peridotitic/ serpentinitic core (Brady 1977; Coleman 1977; Evans 1977; Bucher \& Grapes 2011; Bach et al. 2013). In the ocean floor setting metasomatic reaction zones mark contacts between ultramafic rocks and gabbroic bodies. Reactions like talcification (partial or total) of serpentinites may occur by $\mathrm{Mg}$ remotion or Si addition by diffusion, with the chemical changes occurring in the ultramafic/gabbro contact, or by infiltration, when the metasomatic fluids are formed by the gabbro/ocean water interaction and posteriorly infiltrate the ultramafic body through faults and fractures (Bach et al. 2013; Klemd 2013). Some factors, like the presence of zircon and ilmenite (1-2\%) in the chloritites and their enrichment in REE, suggest that these rocks represent the contact zone between a former serpentinite body and a granitic intrusion, similar to what can be found, in a continental setting, in the Ronda Peridotites, Betic Cordilleras, Spain (Esteban et al. 2007).

\section{CONCLUSIONS}

Based on major, minor and trace composition, a peridotite protolith is suggested for the meta-ultramafic rocks. The serpentinization of these protoliths may have happened in the ocean floor by rock/ocean water interaction. The serpentinites were subsequently metasomatized probably in a continental crust setting, forming zones of talcification, chloritization and tremolitization.

The major, minor and trace elements suggest oceanic gabbroic/basaltic protoliths to the meta-mafic unit rocks. These protoliths may have been formed in a supra-subduction zone setting, with magma source contamination by sediments and subduction zone-derived fluids by the closure of a back-arc basin.

The two studied metagabbro xenoliths within Pinheiro Machado Complex granitoids, collected near the northeastern limit of Ayrosa Galvão Shear Zone, have similar geochemical features to the meta-mafics located further southwest. It confirms the presence of Arroio Grande Ophiolitic Complex rocks further northeast.

The results of this lithogeochemistry study, along with field relationships, rock associations and petrographic evidences, support an oceanic setting to the protoliths of the meta-ultramafic and meta-mafic units. The hypothesis that these rocks represent metamorphosed slices of an ophiolitic complex still seems to be the most reasonable one.

\section{ACKNOWLEDGMENTS}

Fundação de Amparo à Pesquisa do Estado do Rio Grande do Sul (FAPERGS; proc. PqG 10/1509-0) and Conselho Nacional de Desenvolvimento Científico e Tecnológico (CNPq; proc. PQ 305853/2010-4) for the financial support. 


\section{REFERENCES}

Anonymous. 1972. Ophiolites. Penrose Field Conference. Geotimes, 17:24-25.

Babinski M., Chemale Jr. F., Van Schmus W.R., Hartmann L.A., Silva L.C. 1997. U-Pb and Sm-Nd geochronology of the Neoproterozoic Granitic-Gneissic Dom Feliciano Belt, Southern Brazil. Journal of South American Earth Sciences, 10(3-4):263-274.

Bach W., Jöns N., Klein F. 2013. Metasomatism within the ocean crust. In: Harlov D.E. \& Austrheim H. (eds.). Metasomatism and the chemical transformation of rock: the role of fluids in terrestrial and extraterrestrial processes. Berlin, Springer-Verlag, p. 253-288.

Biermanns, L. 1996. Chemical classification of gabbroic-dioritic rocks, based on $\mathrm{TiO}_{2}, \mathrm{SiO}_{2}, \mathrm{FeO}_{\text {tot }}, \mathrm{MgO}, \mathrm{K}, \mathrm{O}, \mathrm{Y}$ and $\mathrm{Zr}$. In: III International Symposium on Andean Geodynamics. Saint-Malo, Proceedings, p. 547-550.

Brady J.B. 1977. Metasomatic zones in metamorphic rocks. Geochimica et Cosmochimica Acta, 41:113-125.

Bucher K. \& Grapes R. 2011. Petrogenesis of metamorphic rocks. Berlin, Springer-Verlag, $428 \mathrm{p}$.

Coleman R.G. 1977. Ophiolites: ancient oceanic lithosphere? Berlin, Springer-Verlag, $229 \mathrm{p}$

D’Orazio M., Boschi C., Brunelli D. 2004. Talc-rich hydrothermal rocks from the St. Paul and Conrad fracture zones in the Atlantic Ocean. European Journal of Mineralogy, 16:73-83.

Da Silva L.C., Hartmann L.A., McNaughton N.J., Fletcher I.R. 1999. SHRIMP U/Pb zircon dating of Neoproterozoic granitic magmatism and collision in the Pelotas Batholith, southernmost Brazil. International Geology Review, 41:531-551.

De Hoog C.J., Janák M., Vrabec M., Froitzheim N. 2009. Serpentinised peridotites from an ultrahigh pressure terrane in the Pohorje Mts. (Eastern Alps, Slovenia): geochemical constraints on petrogenesis and tectonic setting. Lithos, 109(3-4):209-222.

Dilek Y. \& Furnes H. 2011. Ophiolite genesis and global tectonics: geochemical and tectonic fingerprinting of ancient oceanic lithosphere. Geological Society of America Bulletin, 123(3-4):387-411.

Dilek, Y. \& Furnes, H. 2014. Ophiolites and their origins. Elements, 10(2):93-100.

Dilek Y., Furnes H., Shallo M. 2007. Suprasubduction zone ophiolite formation along the periphery of Mesozoic Gondwana. Gondwana Research, 11:453-475.

Dilek Y. \& Newcomb S. (eds.). 2003. Ophiolite concept and the evolution of geological thought. Boulder, Geological Society of America, Special Paper, 373, 504 p.

Dilek Y. \& Robinson P.T. (eds.). 2003. Ophiolites in Earth history. London, Geological Society of London, Special Publications, 218, $717 \mathrm{p}$.

Esteban, J.J., Cuevas, J., Tubía, J.M., Liati, A., Seward, D., Gebauer, D. 2007. Timing and origin of zircon-bearing chlorite schists in the Ronda peridotites (Betic Cordilleras, Southern Spain). Lithos, 99:121-135.

Evans B.W. 1977. Metamorphism of alpine peridotite and serpentinite. Annual Review of Earth and Planetary Sciences, 5:397-447.

Fernandes L.A.D., Menegat R., Costa A.F.U., Koester E., Porcher C.C., Tommasi A., Kraemer G., Ramgrab G.R., Camozzato E. 1995. Evolução tectônica do Cinturão Dom Feliciano no Escudo Sul-riograndense: Parte I - uma contribuição a partir do registro geológico. Revista Brasileira de Geociências, 25(4):351-374.
Figueiredo M.C.H., Fragoso César A.R.S., Kronberg B.L. 1990 Litogeoquímica das principais unidades do Batólito Pelotas no Rio Grande do Sul. In: $36^{\circ}$ Congresso Brasileiro de Geologia. Natal, Anais, v. 4, p. $1723-1738$.

Floyd P.A., Göncüoğlu M.C., Winchester J.A., Yaliniz M.K. 2000 Geochemical character and tectonic environment of Neotethyan ophiolitic fragments and metabasites in the Central Anatolian Crystalline Complex, Turkey. In: Bozkurt E., Winchester J.A., Piper J.D.A. (eds.). Tectonics and magmatism in Turkey and the surrounding area. London, Geological Society of London, Special Publications, 173, p. 183-202.

Floyd P.A. \& Winchester J.A. 1975. Magma type and tectonic setting discrimination using immobile elements. Earth and Planetary Science Letters, 27:211-218.

Fragoso César A.R.S., Figueiredo M.C.H., Soliani Jr. E., Faccini U.F. 1986. O Batólito Pelotas (Proterozóico Superior/Eo-Paleozóico) no Escudo do Rio Grande do Sul. In: $34^{\circ}$ Congresso Brasileiro de Geologia. Goiânia, Anais, v. 3, p. 1322-1343.

Frimmel H.E. 2011. The Chameis Gate Member, Chameis Group, Marmora Terrane, Namibia. In: Arnaud E., Halverson G.P., Shields-Zhou G. (eds.). The geological record of Neoproterozoic glaciations, v. 36. London, Geological Society of London, Memoirs, p. 217-221.

Godard M., Bosch D., Einaudi F. 2006. A MORB source for low-T magmatism in the Semail ophiolite. Chemical Geology, 234:58-78.

Hartmann, L.A. \& Remus, M.V.D. 2000. Origem e evolução das rochas ultramáficas do Rio Grande do Sul desde o Arqueano até o Cambriano. In: Holz, M. \& De Ros, L.F. (eds.) Geologia do Rio Grande do Sul. Porto Alegre, CIGO/UFRGS, p. 53-78.

Hawkesworth C.J., Gallagher K., Hergt J.M., McDermott F. 1993. Mantle and slab contribution in arc magmas. Annual Review of Earth and Planetary Sciences, 21:175-204.

Hawkins J.W. 2003. Geology of supra-subduction zones: implications for the origin of ophiolites. In: Dilek Y. \& Newcomb S. (eds.). Ophiolite concept and the evolution of geological thought. Boulder, Geological Society of America, Special Paper, 373, p. 227-268.

Klemd R. 2013. Metasomatism during high-pressure metamorphism: eclogites and blueschist-facies rocks. In: Harlov D.E. \& Austrheim H. (eds.). Metasomatism and the chemical transformation of rock: the role of fluids in terrestrial and extraterrestrial processes. Berlin, Springer-Verlag, p. 351-413.

Koglin N., Kostopoulos D., Reischmann T. 2009. The Lesvos mafic-ultramafic complex. Greece: ophiolite or incipient rift? Lithos, 108:243-261.

Kusky T.M., Wang L., Dilek Y., Robinson P., Peng S., Huang X. 2011. Application of the modern ophiolite concept with special reference to Precambrian ophiolites. Science China, Earth Sciences, 54(3):315-341

Leite J.D. 1997. A origem dos harzburgitos da Sequência Cerro Mantiqueiras e implicações tectônicas para o desenvolvimento do Neoproterozóico da porção oeste do Escudo Sul-Rio-Grandense. PhD Thesis, Universidade Federal do Rio Grande do Sul, Porto Alegre, $224 \mathrm{p}$

Lenz C., Porcher C.C., Fernandes L.A.D., Masquelin H., Koester E., Conceição R.V. 2013. Geochemistry of the Neoproterozoic (800 $767 \mathrm{Ma}$ ) Cerro Bori orthogneisses, Dom Feliciano Belt in Uruguay: tectonic evolution of an ancient continental arc. Mineralogy and Petrology, 107(5):785-806 
Marini J.C., Chauvel C., Maury R.C. 2005. Hf isotope compositions of northern Luzon arc lavas suggest involvement of pelagic sediments in their source. Contributions to Mineralogy and Petrology, 149:216-232.

Marques J.C., Roisenberg A., Jost H., Frantz J.C., Teixeira R.S. 2003. Geologia e geoquímica das rochas metaultramáficas da Antiforme Capané, Suíte Metamórfica Porongos, RS. Revista Brasileira de Geociências, 33(1):83-94

McDonough W.F. \& McCulloch M.T. 1987. The southeast Australian lithospheric mantle: isotopic and geochemical constraints on its growth and evolution. Earth and Planetary Science Letters, 86:327-340.

McDonough W.F. \& Sun S.S. 1995. The composition of the Earth. Chemical Geology, 120:223-254.

Metcalf R.V. \& Shervais J.W. 2008. Suprasubduction-zone ophiolites: is there really an ophiolite conundrum? In: Wright J.E. \& Shervais J.W. (eds.). Ophiolites, arcs, and batholiths: a tribute to Cliff Hopson. Boulder, Geological Society of America, Special Paper, 438, p. 191-222.

Metcalf R.V., Wallin E.T., Willse K.R., Muller E.R. 2000. Geology and geochemistry of the ophiolitic Trinity terrane, California: evidence of middle Paleozoic depleted supra-subduction zone magmatism in a proto-arc setting. In: Dilek Y., Moores E., Elthon D., Nicolas A. (eds.). Ophiolites and oceanic Crust: new insights from field studies and the ocean drilling program. Boulder, Geological Society of America, Special Paper, 349, p. 403-418.

Paulick H., Bach W., Godard M., De Hoog J.C.M., Suhr G., Harvey J. 2006. Geochemistry of abyssal peridotites (Mid-Atlantic Ridge, $15^{\circ} 20^{\prime} \mathrm{N}$, ODP Leg 209): implications for fluid/rock interaction in slow spreading environments. Chemical Geology, 234:179-210.

Pearce J.A. 1982. Trace element characteristics of lavas from destructive plate boundaries. In: Thorpe R.S. (ed.). Andesites. Chichester, Wiley, p. 525-548.

Pearce J.A., Lippard S.J., Roberts S. 1984. Characteristics and tectonic significance of supra-subduction zone ophiolites. In: Kokelaar B.P. \& Howells M.F. (eds.). Marginal basin geology: volcanic and associated sedimentary and tectonic processes in modern and ancient marginal basins. London, Geological Society of London, Special Publications, 16, p. 77-94.

Pearce J.A. \& Stern R.J. 2006. The origin of Back-arc Basin Magmas: trace element and isotopic perspectives. In: Christie D.M., Fisher C.R., Lee S.M., Givens S. (eds.). Back-Arc spreading systems: geological, biological, chemical, and physical interactions. Washington, American Geophysical Union Monograph, 166, p. 63-86.

Peel E., Basei M., Sanchez Bettucci L. 2009. La Tuna Complex: a possible neoproterozoic ophiolite. In: American Geophysical Union Joint Assembly. Toronto, Abstracts.

Peltonen P. \& Kontinen A. 2004. The Jormua ophiolite: a mafic-ultramafic complex from an ancient ocean-continent transition zone. In: Kusky T.M. (ed.). Precambrian ophiolites and related rocks. Amsterdam, Elsevier, Developments in Precambrian Geology, v. 13, p. 35-71.

Philipp R.P., Machado R., Nardi L.V.S., Lafon J.M. 2002. O magmatismo granítico neoproterozóico do Batólito Pelotas no sul do Brasil: novos dados e revisão da geocronologia regional. Revista Brasileira de Geociências, 32(2):277-290.

Plank T. 2005. Constraints from Thorium/Lanthanum on sediment recycling at subduction zones and the evolution of the continents. Journal of Petrology, 46(5):921-944.
Porter K.A. \& White W. 2003. The deep mantle subduction flux and its implications for mantle $\mathrm{Th} / \mathrm{U}$ and $\mathrm{Pb} / \mathrm{Ce}$ ratios. In: American Geophysical Union, Fall Meeting Supplement. San Francisco, Abstracts.

Ramos, R.C. 2011. Geologia da associação metamáfica-ultramáfica da região de Arroio Grande, RS. Bachelor Monography, Universidade Federal do Rio Grande do Sul, Porto Alegre, 94 p.

Ramos R.C. \& Koester E. 2013. O Complexo Ofiolítico Arroio Grande, sudeste do Escudo Sul-Rio-Grandense. In: $8^{\circ}$ Simpósio Sul-brasileiro de Geologia. Porto Alegre, Abstracts.

Ramos R.C. \& Koester E. 2014. Geologia da associação metamáfica-ultramáfica da região de Arroio Grande, sudeste do Escudo Sul-Rio-Grandense. Pesquisas em Geociências, 41(1):25-38.

Ramos R.C., Koester E., Masquelin H. 2013. Significado tectônico do Complexo Arroio Grande (Brasil) - La Tuna (Uruguai) e seus possíveis equivalentes neoproterozoicos namibianos. In: $7^{\circ}$ Congreso Uruguayo de Geología y 10 Simposio de Minería y Desarrollo del Cono Sur. Montevideo, Abstracts, p. 138-143.

Rollinson H.R. 2007. Early earth systems: a geochemical approach. New York, Blackwell, 296 p.

Spandler C., Hermann J., Faure K., Mavrogenes J.A., Arculus R.J. 2008. The importance of talc and chlorite "hybrid" rocks for volatile recycling through subduction zones: evidence for the high-pressure subduction mélange of New Caledonia. Contributions to Mineralogy and Petrology, 155:181-198.

Strieder, A.J. 1992. Serpentinização e metassomatismo em rochas ultramáficas: discussão das características e recomendações para o tratamento geoquímico. Revista Brasileira de Geociências, 22(3):329-337.

Strieder A.J. \& Nelson A.A. 1992. Estudo petrológico de alguns fragmentos tectônicos da melange ofiolítica em Abadiânia (GO): I - os protólitos dos corpos de serpentinito. Revista Brasileira de Geociências, 22(3):338-352.

Sun S.S. \& McDonough W.F. 1989. Chemical and isotopic systematics of oceanic basalts: implications for mantle composition and processes. In: Saunders A.D. \& Norry M.J. (eds.). Magmatism in ocean basins. London, Geological Society of London, Special Publications, 42, p. 313-345.

Thompson R.N., Morrison M.A., Hendry G.L., Parry S.J., Simpson P.R., Hutchison R., O'Hara M.J. 1984. An assessment of the relative roles of crust and mantle in magma genesis: an elemental approach (and discussion). Philosophical Transactions of the Royal Society of London, 310(1514):549-590.

Wildner W., Ramgrab G.E., Lopes R.C., Iglesias C.M.F. 2005. Mapa Geológico do Estado do Rio Grande do Sul, escala 1:750.000. Porto Alegre, CPRM - Serviço Geológico do Brasil.

Wilson M. 1989. Igneous petrogenesis: a global tectonic approach. London, Chapman \& Hall, 466 p.

Wood D.A., Marsh N.G. Tarney J., Joron J.L., Fryer P., Treuil M. 1981. Geochemistry of igneous rocks recovered from a transect across the Mariana trough, arc, fore-arc, and trench, sites 453 through 461, Deep Sea Drilling Project Leg 60. In: Hussong D.M., Uyeda S., Blanchet R., Bleil U., Ellis C.H., Francis T.J.G., Fryer P., Horai K.I., Kling S., Meijer A., Nakamura K., Natland J.H., Packham G.H., Sharaskin A. (eds.). Initial reports of the Deep Sea Drilling Project. Washington, United States Government Printing, v. 60, p. 611-645.

Arquivo digital disponível on-line no site www.sbgeo.org.br 